\title{
Variable FMR1 gene methylation of large expansions leads to variable phenotype in three males from one fragile $\mathrm{X}$ family
}

\author{
Bert B A de Vries, Carola C A M Jansen, Annelien A Duits, Coleta Verheij, \\ Rob Willemsen, Jan $O$ van Hemel, Ans $M$ W van den Ouweland, \\ Martinus F Niermeijer, Ben A Oostra, Dicky J J Halley
}

\begin{abstract}
The fragile $X$ syndrome is caused by an expanded CGG repeat ( $>200$ units, full mutation) at the $5^{\prime}$ end of the FMR1 gene, which is associated with methylation of a CpG island upstream of the FMR1 gene and down regulation of the transcription.

We describe three related males with full mutations in the FMR1 gene, as defined by size, but with different percentages of unmethylated alleles $( \pm 90 \%, 35 \%$, and $15 \%$, respectively) as studied in leucocytes. Normal mental status was observed in the male who showed $90 \%$ lack of methylation, whereas his two cousins were retarded. The mentally normal male did show some minor facial features of the fragile $X$ syndrome; the FMR protein was detectable in $75 \%$ of his leucocytes. In all three cases, the proportion of unmethylated FMR1 genes corresponded to the percentage of leucocytes showing FMR1 protein production. Our results indicated a direct relationship between methylation and the ability to produce FMR protein.

These cases will be discussed in relation to the phenotypic effects of incompletely methylated full mutations in the FMR1 gene as observed by others.

( $f$ Med Genet 1996;33:1007-1010)
\end{abstract}

Clinical Genetics

University Hospital

Dijkzigt and Erasmus

University Rotterdam,

P O Box 1738,

3000 DR Rotterdam,

The Netherlands

B B A de Vries

C C A M Jansen

C Verheij

$R$ Willemsen

J O van Hemel

A $M$ W van den

Ouweland

M F Niermeijer

B A Oostra

D J J Halley

Department of Medical Psychology and Psychotherapy, University Hospital Dijkzigt and Erasmus University Rotterdam, P O Box 1738, 3000 DR Rotterdam,

The Netherlands

A A Duits

Correspondence to: Dr de Vries.

Received 12 April 1996 Revised version accepted for publication 21 June 1996

Key words: fragile $\mathrm{X}$ syndrome; methylation; protein expression; clinical variability.

In the FMR1 gene, ${ }^{1-4}$ which is involved in the fragile $X$ syndrome, a polymorphic CGG repeat is present in the first exon. The number of CGG repeats varies between six and 54 in the normal population. Phenotypically normal male and female premutation carriers of this $\mathrm{X}$ linked disorder have repeats in the range 54 to 200. A full mutation is defined by a repeat length $>200$. The full mutation is associated with methylation of the $\mathrm{CpG}$ island upstream of the FMR1 gene and with the subsequent sequently, the absence of the FMR1 protein. ${ }^{35}$ The latter is regarded as the major cause of mental retardation in male and female fragile $\mathrm{X}$ patients. ${ }^{5}$ Recently, Feng et at suggested a reduced translation of unmethylated FMR1 alleles with $>200$ repeats, leading to diminished FMR1 protein production as a direct result of the repeat size.
We report a mentally normal male with an FMR1 gene trinucleotide repeat expansion of $>200$ repeats and an almost complete $( \pm 90 \%)$ lack of methylation. His two retarded cousins also had full mutations, as defined by size, but showed higher degrees of methylation. The FMR protein was assayed in leucocytes of these three related males. Our data indicated that methylation and not the length of the repeat is the primary determinant of diminished FMR1 protein production.

\section{Patients and methods}

The three males who are the subjects of this report were cousins from one fragile $\mathrm{X}$ family. The family was ascertained through the brother of case 3, who was referred to our Department of Clinical Genetics for genetic counselling.

\section{DNA ANALYSIS}

Genomic DNA was isolated ${ }^{7}$ from blood leucocytes and fibroblasts, digested with HindIII or HindIII + the methylation sensitive enzyme EagI, and hybridised with probe pP2 according to standard protocols. ${ }^{8}$ The autoradiograms were made in duplicate and with different exposure times, and analysed by densitometry shut down of gene transcription and, con-
PROTEIN ANALYSIS

Blood smears were made from one drop of blood within two hours after collection. Slides were air dried, frozen, and stored at $-80^{\circ} \mathrm{C}$. The FMR1 protein was visualised by using mouse monoclonal antibodies $1 \mathrm{Al}$ against FMR1 protein followed by a second incubation step with goat antimouse immunoglobulin conjugated with biotin (DAKO) according to the procedures described previously. ${ }^{9}$

\section{DETERMINATION OF IQ LEVELS}

The Wechsler Adult Intelligence Scale (WAIS) was used to test the intellectual abilities by one examiner $(\mathrm{AD})$ who was not informed about the genetic status of the persons tested. The verbal, performance, and full scale IQ scores were calculated. 

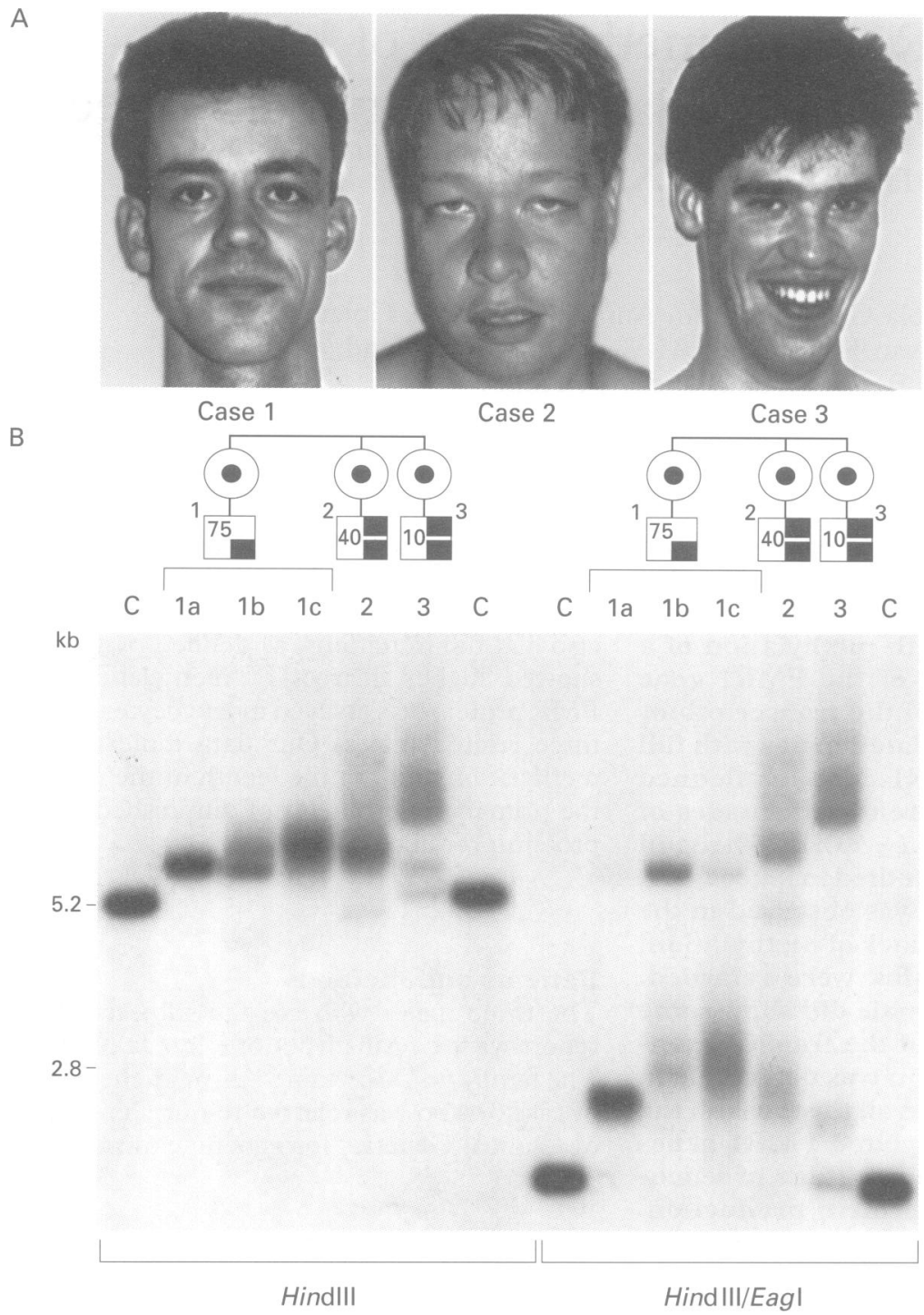

Figure 1 (A) Cases 1, 2, and 3. Note a long face with a prominent chin and high, broad forehead in case 1, high, broad forehead and periorbital fullness in case 2 , and a long, narrow face with a prominent chin in case 3. (B) Pedigree of cases 1-3. Filled lower right box $=$ minor or major fragile $X$ physical features present, filled upper right box $=$ mental retardation present, number in left half $=$ percentage of leucocytes expressing the FMR protein, and analysis with probe pP2 of HindIII (left) and HindIII/EagI (right) digested DNA of case 1 (lane 1a, fibroblasts; lane $1 b, E B V$ transformed lymphoblasts; lane 1c, leucocytes), case 2 (lane 2, leucocytes), case 3 (lane 3, leucocytes), and several normal male controls (lanes $C$ ).

\section{Results}

\section{CASE REPORTS}

Case 1

This 29 year old man (fig 1A) was examined because of a family history of the fragile $\mathrm{X}$ syndrome. He showed a normally proportioned male phenotype, height $193 \mathrm{~cm}$ (98th centile) and head circumference $58 \mathrm{~cm}$ (90th centile). He had a long face with a prominent chin, high forehead, normally sized but everted ears, and dental crowding in the lower jaw. Testicular size was normal $(25 \mathrm{ml} / 25 \mathrm{ml})$. Apart from the facial characteristics, no other fragile $\mathrm{X}$ features, for example, behavioural symptoms, were seen.

His full scale IQ level (WAIS) was 101 points with a verbal scale IQ score of 108 and performance scale IQ score of 92 . His sister with normal FMR1 genes had a full scale IQ of 115 and the sister with a premutation had a score of 96 .
Chromosome studies in folic acid deficient medium $^{10}$ showed a normal $46, \mathrm{XY}$ karyotype in cells of case 1, without expression of the fragile site at $\mathrm{Xq} 27$.

\section{Case 2}

This 27 year old mentally retarded cousin of case 1 (fig 1A) had several physical features of the fragile $\mathrm{X}$ syndrome, including high, broad forehead, periorbital fullness, macro-orchidism (>35 ml), hyperlaxity of small and large joints with pes planus and genu valgum, a simian crease on the left palm, and soft velvety skin. Typical fragile $\mathrm{X}$ behavioural characteristics were avoidance of eye contact, hand flapping, and hand biting. Because of his refusal to speak to strangers, IQ testing was not possible; he attended a special school for the mentally retarded.

\section{Case 3}

The other mentally retarded cousin (fig 1A) of the same age (27 years) had a long, narrow face, prominent chin, flat feet, and macro-orchidism $(50 \mathrm{ml} / 50 \mathrm{ml})$. Typical fragile $\mathrm{X}$ behaviour included avoidance of eye contact, obsession with neatness, hand rubbing, and murmuring to himself. Twenty percent expression of the fragile site at Xq27 was observed in lymphocytes cultured in folic acid deficient medium. ${ }^{10}$

\section{MOLECULAR FINDINGS}

In case 1 , leucocytes with an expansion of 200 to 800 CGG repeats of the FMR1 gene were found by DNA analysis. Double digestion with HindIII and the methylation sensitive restriction enzyme EagI showed that $90 \%$ of the alleles were unmethylated (as estimated by densitometry; fig $1 \mathrm{~B}$, lane $1 \mathrm{c}$, right). To assess whether cells with such alleles were able to express FMR protein (FMRP), further studies were initiated. The FMRP was detectable in $75 \%$ of leucocytes by antibody testing in a blood smear (normal male control 90\%). Apart from cells derived from fresh blood, cultured fibroblasts and an EBV transformed lymphoblastoid cell line were also tested. In fibroblasts the size of the CGG repeat was estimated to be 200 repeat units and methylation was absent (fig 1B, lane 1a, left and right). EBV transformed lymphoblasts showed a full mutation (size 200-300 repeats) and methylation in 70\% of the cells (fig 1B, lane $1 \mathrm{~b}$ ). Less than $5 \%$ of the lymphoblasts expressed FMR protein. Most probably, the results reflect clonal effects.

In case 2 , a full mutation, sized 200 to 1300 repeats, was found in his leucocytes. By methylation assay, the alleles were shown to be partially unmethylated (35\%) (fig 1B). Protein analysis in blood smears showed 40\% FMRP production in his leucocytes (controls: fragile $\mathrm{X}$ male $2 \%$ and normal male $90 \%$ ).

In case 3, the leucocytes showed a full mutation in the FMR 1 gene (size 400-1600 repeats, fig 1B). Absence of methylation was found in $15 \%$ of the alleles. The protein antibody test 


\begin{tabular}{|c|c|c|c|c|c|c|c|c|c|c|c|c|c|c|}
\hline & \multicolumn{11}{|c|}{ References } & & & \\
\hline & \multicolumn{3}{|l|}{13} & \multicolumn{3}{|l|}{14} & \multicolumn{2}{|l|}{11,15} & 6 & \multicolumn{2}{|l|}{16} & \multicolumn{3}{|c|}{ Current family } \\
\hline & $I$ & II & $I I I$ & $I V$ & $V$ & $V I$ & $V I I$ & $V I I I$ & $I X$ & $X$ & $X I$ & Case 1 & Case 2 & Case 3 \\
\hline Age & 36 & 45 & 43 & 12 & 13 & 22 & 29 & 8 & 1.6 & 74 & 72 & 29 & 27 & 27 \\
\hline No in original report & II. 6 & II. 2 & II. 3 & 2 & 3 & 25 & III.5 & 14 & III. 2 & 7298 & 7241 & & & \\
\hline DNA (leucocytes) & & & & & & & & & & & & & & \\
\hline \multicolumn{15}{|l|}{ Expansion size full mutation* } \\
\hline Smallest & $170 /$ & $130 /$ & $100 /$ & 160 & $115 /$ & $150 /$ & $130 /$ & $230 /$ & $266+$ & $170 /$ & $100 /$ & $200 /$ & $200 /$ & $400 /$ \\
\hline Largest & 530 & 200 & 270 & 1270 & 850 & 1250 & 470 & 300 & & 340 & 1500 & 800 & 1300 & 1600 \\
\hline Unmethyl full mutation (\%) & 55 & 97 & 97 & 100 & 100 & 100 & 60 & 90 & 100 & 100 & 100 & 90 & 35 & 15 \\
\hline $\begin{array}{l}\text { FMR protein } \\
\text { Western blot }(\%)\end{array}$ & & & & & & & & & & & & & & \\
\hline $\begin{array}{l}\text { Western blot (\%) } \\
\text { Cells expressing FMRP (\%) }\end{array}$ & & & & & & $35 \ddagger$ & & & $12 \dagger$ & Red $\neq \emptyset$ & Red $\neq \S$ & & & \\
\hline \multicolumn{14}{|l|}{ Phenotype } & 10 \\
\hline MR\| & + & - & - & - & - & & -9 & \pm & NK & -9 & -9 & - & + & + \\
\hline Physical features & Yes & Minor & Minor & Minor & Minor & $\overline{\bar{M}}$ inor & Minor & $\overline{\text { Yes }}$ & Minor & No & No & Minor & Yes & Yes \\
\hline Fragile X (\%) & 11 & 0 & 0 & 4 & 5 & 4 & $1-4$ & 3 & & 6 & 13 & 0 & & 20 \\
\hline
\end{tabular}

*Number of repeats, if necessary, estimated from the sizes $(\mathrm{kb})$ in the original reports.

†Fibroblast cell line.

$\ddagger$ Lymphoblast cell line.

SReported reduced but not quantitated.

$\|$ Mental retardation: $+=\mathrm{IQ}<70 ; \pm=70<\mathrm{IQ}<85 ;-=\mathrm{IQ}>85$.

IMental status clinically estimated without specific IQ testing.

$\mathrm{NK}=$ Not known.

showed $10 \%$ of the leucocytes expressing the FMR protein.

All three mothers of these males were carriers of a premutation.

\section{Discussion}

The cases described here belong to a subgroup of subjects from fragile $\mathrm{X}$ families with "methylation mosaicisn"." In a large multicentre study, "methylation mosaicism" was observed in 3\% (15/500) of the males with a full mutation; two males had large unmethylated mutations ( $>230$ repeats), but additional molecular and clinical data were not reported. ${ }^{12}$ Table 1 is an overview of clinical and molecular data of 14 currently known cases. $^{6113-16}$ The presence of facial characteristics of the fragile $\mathrm{X}$ syndrome with normal mental capacities is interesting (case 1 of this report and other reports, table 1). Rousseau et al ${ }^{15}$ reported a normally functioning male with 130 to 470 CGG repeats and lack of methylation in $60 \%$ of his leucocytes, who also displayed some minor fragile $\mathrm{X}$ features. These observations suggest different thresholds for phenotypic expression of the full mutation in different tissues or during different critical times in development. Remarkably, the combination of normal intellectual development and facial fragile $\mathrm{X}$ features has also been observed in female obligate carriers with cytogenetic expression, ${ }^{17}$ suggesting a more common phenomenon.

The methylation of a $\mathrm{CpG}$ island upstream of the FMR1 gene has been associated with the lack of transcription in males with a full mutation. Studying "methylation mosaics" might shed light on mechanisms concerning translation of unmethylated expanded FMR1 alleles. The existence of this special genotype indicates that amplification occurs before methylation. ${ }^{18}$ So far, few FMRP studies have been performed in tissues of "methylation mosaics". Recently, Feng et al reported markedly diminished FMRP production in fibroblast clones from transcripts with more than 200 repeats, suggesting a hindrance of $40 \mathrm{~S}$ ri- bosomal subunit migration along the $>200$ repeats. However, in the three cousins reported here a direct relationship is seen between the percentage of unmethylated full mutations in leucocytes, protein production, and cognitive function, suggesting normal translation of expanded unmethylated FMR1 alleles. This is also supported by the observation of Smeets et $a l^{16}$ of two mentally normal males with unmethylated full mutations and FMR1 protein expression, not only in all leucocytes, but also in a lymphoblast cell line with a single repeat length of 400 . This observation and our own also show that the clonal effects observed in cell lines make them less informative for routine diagnostic studies.

The mental retardation of case 2 , who has FMRP production in $40 \%$ of his leucocytes, suggests that protein expression at and below this level is insufficient for normal cognitive functioning. This is in line with another report of a retarded male with the fragile $\mathrm{X}$ phenotype who had $28 \%$ FMR1 protein expression owing to a deletion in a proportion of his cells. ${ }^{19}$ The observed situation is reminiscent of females heterozygous for the full mutation in the FMR1 gene who are affected in $60-75 \%$ of cases ${ }^{1220}$ with a positive correlation between the proportion of normal FMR1 alleles on the active (unmethylated) $\mathrm{X}$ chromosome and IQ. ${ }^{20} \mathrm{Al}$ though FMR protein expression studies have not been performed in brain tissue of female full mutation carriers or methylation mosaic males, it seems that in neither case does compensation of deficient brain cells by cells expressing the normal protein occur to a sufficient level.

The present data suggest that methylation is directly involved in down regulation of transcription and indicate that transcripts with more than 200 repeats can normally be translated into FMR protein in vivo. Further studies might focus on developing a technique of selective demethylation at the FMR1 locus in order to restore transcription and translation. However, as an FMR protein level at least over $40 \%$ of normal is likely to be required for 
normal cognitive development, as far as can be judged from leucocytes, this will be difficult to achieve.

We are grateful to Professor H Galjaard and the Foundation for Clinical Genetics, Rotterdam for their continuous support.

1 Verkerk AJMH, Pieretti M, Sutcliffe JS, et al. Identification of a gene (FMR-1) containing a CGG repeat coinciden with a breakpoint cluster region exhibiting length variation in fragile X syndrome. Cell 1991;65:905-14.

2 Yu S, Pritchard M, Kremer E, et al. Fragile X genotype characterized by an unstable region of DNA. Science 1991 252:1179-81.

3 Oberlé I, Rousseau F, Heitz D, et al. Instability of a 550 base pair DNA segment and abnormal methylation in fragile X syndrome. Science 1991;252:1097-102.

$4 \mathrm{Fu}$ YH , Kuhl DPA, Pizzutti A, et al. Variation of the CGG repeat at the fragile $\mathrm{X}$ site results in genetic instability: resolution of the Sherman paradox. Cell 1991;67:1047-58.

5 Pieretti M, Zhang F, Fu YH, et al. Absence of expression of the FMR-1 gene in fragile X syndrome. Cell 1991;66: of the FMr

6 Feng Y, Zhang F, Lokey LK, et al. Translational suppression by trinucleotide repeat expansion at FMR1. Science 1995 268:731-4

7 Miller SA, Dykes DD, Polesky HF. A simple salting out procedure for extracting DNA from human nucleated cells. Nucleic Acids Res 1988;16:1214.

8 Oostra BA, Jacky PB, Brown WT, Rousseau F. Guidelines for the diagnosis of the fragile $\mathrm{X}$ syndrome. $\mathcal{f}$ Med Genet 1993;30:410-13.

9 Willemsen R, Mohkamsing S, De Vries B, et al. Rapid antibody test for fragile X syndrome. Lancet 1995;345: 1147-8.
10 Sutherland GR. Fragile sites on human chromosomes: demonstration of their dependence on the type of tissue culture medium. Science 1977;197:265-6.

11 Rousseau F, Heitz D, Biancalana V, et al. Direct diagnosis by DNA analysis of the fragile $X$ syndrome of mental retardation. N Engl f Med 1991;325:1673-81.

12 Rousseau F, Heitz D, Tarleton J, et al. A multicenter study on genotype-phenotype correlations in the fragile $\mathrm{X}$ synon genotype-phenotype correlations in the fragile X synfrome, using direct diagnosis with probe StB12.3:

13 McConkie-Rosell A, Lachiewicz AM, Spiridigliozzi GA, $e$ al. Evidence that methylation of the FMR-1 locus is responsible for variable phenotypic expression of the fragile $\mathrm{X}$ syndrome. Am $\mathcal{F}$ Hum Genet 1993;53:800-9.

14 Hagerman RJ, Hull CE, Safanda JF, et al. High functioning fragile X males: demonstration of an unmethylated fully expanded FMR-1 mutation associated with protein expression. Am f Med Genet 1994;51:298-308.

15 Rousseau F, Robb LJ, Rouillard P, Der Kaloustian VM. No mental retardation in a man with $40 \%$ abnormal methylation at the FMR-1 locus and transmission of sperm cell mutations as premutations. Hum Mol Genet 1994;3: 927-30.

16 Smeets HJM, Smits APT, Verheij CE, et al. Normal phenotype in two brothers with a full FMR 1 mutation. Hum Mol Genet 1995;4:2103-8.

17 Fryns JP. The female and the fragile X: a study of 144 obligate female carriers. Am $\mathcal{F}$ Med Genet 1986;23:157-69. 18 Sutcliffe JS, Nelson DL, Zhang F, et al. DNA methylation represses FMR-1 transcription in fragile $\mathrm{X}$ syndrome. Hum Mol Genet 1992;1:397-400.

19 De Graaff E, De Vries BBA, Willemsen R, et al. The fragile $\mathrm{X}$ phenotype in a mosaic male with a deletion showing expression of the FMR1 protein in $28 \%$ of the cells. $A m$ f Med Genet 1996;64:302-8.

20 De Vries BBA, Wiegers AM, Smits APT, et al. Mental status of females with a FMR1 gene full mutation. $\mathrm{Am} \mathcal{F} \mathrm{Hum}$ Genet 1996;58:1025-32. 